I. - ECONOMICS

\title{
European animal feed: a growing dependence of the world market
}

\author{
D. DARIDAN, Y. DRONNE,
}

I.T.P., Service Économie, 34 bd de la Gare, 3 Io79 Toulouse Cedex I.N.R.A., 3, we du Caducée, B.P. 333, 94153 Rungis Cedex

A simultaneous increase of European livestock and import rates has led to higher mixed feed consumption in Europe. This evolution has been more important in France than in the Netherlands, where industrialization of animal feed developped already 20 years ago. In France, it is necessary to point out the particular situation of Brittany.

Among the raw materials used, we can notice the development of corn. However, insufficient F.E.C. self-supply makes it necessary to buy about $50 \mathrm{p}$. Ioo of the quantities needed outside the E.E.C. Only France is able to export. The U.S.A. are the first E.E.C. suppliers.

Very particular attention must be maid to cereal substitution products, the use of which has been rapidly increasing during the last years. The main users are the Netherlands and Belgium, the countries where animal feeding is most concentrated. They had to enter the world market because of the very low self-supply rate for fodder grains. Among the substitution products, only manioc is an entirely satisfying substitute for cereals. The use of other substitution products means a soybean meal economy.

Soybean meal is the most common protein product. Its use has been increasing since about ten years. However, it seems that the E.E.C. partners mostly try to diversify protein sources. Future supply for France necessarily involves the development of protein seeds.

The U.S.A. are the first soyabean suppliers, but they are now competing with Brazil.

European dependence on the world market for raw materials places animal productions under direct influence of climatic, financial and political factors sometimes leading to important variations. The consequences are all the more important as the US position on the world market is preponderant. It will be particularily difficult to switch from soyabean meal, the more so as cereals are very experisive inside the Common Market comparated to the price of protein products.

\section{French foreign trade in pork}

\author{
C. BRETTE $\left({ }^{1}\right)$, D. DARIDAN $\left({ }^{2}\right)$, A. VIGNE $\left({ }^{2}\right)$ \\ (1) Institut National Agronomique, Centre d'Étude et de Recherche \\ sur l'Économie et l'Organisation des productions animales, \\ 16, rue Claude-Bernard, 7523r Paris Cedex 05 \\ (2) I.T.P., Service Économie, 34, bd da la Gare, 3 ro79 Toulouse Cedex
}

French structural shortage of pork has slightly increased during the last years.

Quantitatively, Belgium and the Netherlands remain the favourite suppliers for France, in spite of a tendency to diversify the origin of French imports since new contries have been admitted in the E.E.C. 